\title{
Pneumothorax in the ICU: Retrospective Analysis of Two Years' Experience
}

\author{
Yoğun Bakım Ünitesinde Pnömotoraks: İki Yıllık Retrospektif \\ Değerlendirme
}

\author{
(D) Ali Özalp, (D Mehmet Salih Sevdi, (D Serdar Demirgan, (D) Funda Gümüş Özcan, (D Myatsu Win, \\ (D) Kerem Erkalp, (D) Ayşin Selcan
}

University of Health Sciences, İstanbul Bağcllar Training and Research Hospital, Clinic of Anesthesiology and Reanimation, İstanbul, Turkey

\section{Abstract}

Objective: Pneumothorax is a common occurrence in intensive care unit (ICU)'s. Whereas causes of traumatic pneumothorax is generally blunt and penetrating traumas, iatrogenic pneumothorax may occur after procedures like central venous catheterization, positive-pressure mechanical ventilation and thoracentesis.

Method: This study evaluated the data from 69 patients diagnosed with pneumothorax and followed up and treated in the ICU between the dates 01.01.2013 and 01.01.2015. The records were used to establish the patients' age, sex, Body Mass index and cause of pneumothorax, as well as the time of insertion of chest tube, total duration of chest tube and ICU length of stay. Pneumothorax patients were evaluated in two groups based on their etiologies as Traumatic Pneumothorax group (Group T) and latrogenic Pneumothorax group.

Results: The pneumothorax incidence in our intensive care unit was found to be $2.53 \%$, and all of the cases were acquired pneumothorax. Fifty-seven out of 69 cases were traumatic, most having developed bilaterally compared to the cases in the iatrogenic group, diagnosed with Computerized Tomography of Thorax and had a higher rate of thoracentesis. In Group T, chest tube was inserted earlier and mechanical ventilation duration and ICU length of stay were shorter.

Conclusion: Pneumothorax is one of main emergency events in ICU patients. Even though it is rare, it should be diagnosed early. Our study confirms that pneumothorax in ICU is always acquired and mostly traumatic. Traumatic pneumothorax is associated with shorter mechanical ventilation duration and shorter ICU length of stay compared to iatrogenic pneumothorax.

\section{Öz}

Amaç: Pnömotoraksa yoğun bakım ünitelerinde (YBÜ) sıklıkla rastlanır Travmatik pnömotoraks sebepleri, genellikle künt ve penetran travmalar iken, iatrojenik pnömotoraks santral venöz kateterizasyon, pozitif basınçlı mekanik ventilasyon ve torasentez gibi işlemler sonrası meydana gelebilmektedir.

Yöntem: Bu çalışmada, YBÜ, 01.01.2013 ile 01.01.2015 tarihleri arasında pnömotoraks tanısı alarak takip ve tedavi edilen toplam 69 hastanın bilgileri değerlendirildi. Hastaların yaş, cinsiyet, Vücut Kitle indeksi ile pnömotoraks nedeni, tarafı, göğüs tüpünün takılma zamanı, göğüs tüpü toplam kalış süresi, YBÜ kalış süresi açısından kayıtlar değerlendirildi. Pnömotoraks hastaları etiyolojilerine göre Travmatik Pnömotoraks grubu (Group T) ve latrogenic pnömotoraks grubu olarak incelendi.

Bulgular: YBÜ'de pnömotoraks insidansı \%2,43 saptandı ve olguların tümü kazanılmış pnömotoraks idi. Olguların 57/69'u travmatik olup, iatrojenik gruptakilere göre, çoğu bilateral gelişmiş, tanıda toraks kompütörize tomografisi kullanılmış ve torasentez sıklığı daha fazla idi. grup T'de göğüs tüpü daha hızlı yerleştirilmişti. Mekanik ventilasyon süresi ve YBÜ'de kalma zamanı grup T'de daha kısaydı.

Sonuç: Pnömotoraks YBÜ'de yatan hastalarda görülen başlıca acil olgulardan biridir. Nadir olmasına rağmen erken teşhis edilmelidir. Çalışmamı, YBÜ'de görülen pnömotoraksın her zaman edinilmiş olduğunu ve çoğunun travmatik olduğunu doğrulamaktadır. Travmatik pnömotoraks grubunda mekanik ventilasyon süresi ve YBÜ'de kalış süresi iatrojenik pnömotoraks grubuna kıyasla daha kısadır.

Anahtar kelimeler: Pnömotoraks, travmatik, iatrojenik, YBÜ

Keywords: Pneumothorax, traumatic, iatrogenic, intensive care unit 


\section{Introduction}

Pneumothorax is categorized into two main groups as spontaneous and traumatic origin (1). Spontaneous pneumothorax is seen in people with or without an underlying respiratory condition and without a trauma history. It is also divided into two subgroups as primary and secondary spontaneous pneumothorax. Primary spontaneous pneumothorax develops in young and healthy individuals with no known Pulmonary disease. Secondary spontaneous pneumothorax, on the other hand, is a complication of an underlying pulmonary pathology (e.g. chronic obstructive pulmonary disease, cystic fibrosis, interstitial lung disease, etc.) (2,3) (Table 1).

Pneumothorax is a common occurrence in intensive care units (ICUs). Most pneumothorax cases in ICUs (70\%) are traumatic. Whereas causes of traumatic pneumothorax are generally blunt and penetrating traumas, iatrogenic pneumothorax may generally occur after procedures like central venous catheterization (CVC), positive-pressure mechanical ventilation (PPMV) and thoracentesis $(4,5)$. Incidence of iatrogenic pneumothorax in critical ICU patients is $4-15 \%$, and it is one of the serious complications of PPMV $(5,6)$.

\section{Material and Methods}

This study retrospectively examined the records of total of 2.839 patients followed up and treated in the Anesthesiology

\section{Table 1. Pneumothorax classification and causes}

\begin{tabular}{ll} 
Pneumothorax & \\
\hline Spontaneous Primary & $\begin{array}{l}\text { Subpleural bleb rupture, } \\
\text { Bullous rupture }\end{array}$ \\
Secondary & COPD, \\
& Tuberculosis, \\
& Necrotizing pneumonia, \\
& Malignancy, \\
Interstitial Lung disease, & Cystic fibrosis \\
Acquired & Blunt trauma, \\
& Penetrating trauma, \\
& Barotrauma \\
& Central venous cannulation, \\
& Pleural biopsy, \\
& Transbronchial biopsy, \\
& Transthoracic needle aspiration biopsy, \\
& Thoracentesis, \\
& Mechanical ventilation
\end{tabular}

COPD: Chronic Obstructive Pulmonary disease and Reanimation Clinic ICU of our hospital between the dates 01.01.2013 and 01.01.2015 having obtained local ethics committee approval. From among the patients admitted to the hospital within said two-year period, the study included the data of 69 patients (22 female and 47 male patients) who were diagnosed with J-93: Pneumothorax, J-94: Other Pleural Conditions, S-21: Open Wound of Thorax, and S-27: Injury of Other and Unspecified Intrathoracic Organs based on the ICD-10 diagnosis codes in the hospital's information system.

The study evaluated the patients' age, sex, height, body weight, Acute Physiology and Chronic Health Evaluation (APACHE)-II score and causes of pneumothorax, as well as radiological diagnostic methods [chest X-ray, computed tomography of thorax (CToT)], presence of thoracentesis, time of post-diagnosis chest tube insertion (hour), and total duration of chest tube (day). The study also evaluated the records in terms of whether patients needed mechanical ventilator as well as mechanical ventilation durations, ICU lengths of stay, and mortality.

\section{Statistical Analysis}

Statistical analyses were conducted using NCSS (Number Cruncher Statistical System) 2007 Statistical Software (Utah, USA) package program. In addition to descriptive statistical methods (mean \pm standard deviation) used to evaluate the data, the study utilized independent t-test to compare binary groups and the chi-square test to compare qualitative data. The results were evaluated according to significance level of $\mathrm{p}<0.05$.

\section{Results}

Demographic data of the patients are given in Table 2. In none of the cases was spontaneous pneumothorax found to be the etiology of pneumothorax. Pneumothorax etiology was acquired pneumothorax in all of 69 patients. Causes of admissions to ICU of traumatic pneumothorax patients $(\mathrm{n}=57)$ and iatrogenic pneumothorax patients $(\mathrm{n}=12)$ are given in Table 3.

ICU lengths of stay of patients were higher in Iatrogenic Pneumothorax group (group I) than Traumatic Pneumothorax group (group T). The thoracic tube was inserted earlier group T compared to group I. ICU data of acquired pneumothorax patients are given in Table 4. ICU lengths of stay of patients were higher in group I than group $\mathrm{T}$. The thoracic tube was inserted earlier group $\mathrm{T}$ compared to group I. 


\section{Discussion}

The data of this study includes the pneumothorax cases followed up in the ICU. It was found out that acquired pneumothorax was the etiology in all of the patients. The reason for this may be the absence of pulmonary diseases Clinic and Chest Surgery Clinic in our hospital and the referral of primary spontaneous pneumothorax and secondary spontaneous pneumothorax patients to branch hospitals by the emergency service or the emergency assistance command center. Records of 69 out of 2.838 patients admitted to the ICU showed pneumothorax diagnosis. Based on such data, it was found out that the pneumothorax incidence in our ICU was $2.43 \%$. The body of literature shows that ICU pneumothorax incidence is $5-12 \%(7)$. The reason why the incidence is lower in our study may be attributable to omitting to check off pneumothorax in the diagnosis codes searched during the retrospective scanning.

All of the cases in our ICU were acquired pneumothoraxes. Acquired pneumothoraxes are categorized in two groups: traumatic and iatrogenic. Traumatic pneumothorax develops in $15-20 \%$ of the patients exposed to blunt trauma (8). Mortality rate in traumatic pneumothoraxes is $26.32 \%$. On the other hand, the likelihood of bilateral pneumothorax in thoracic traumas is only $3 \%$; however, the mortality is higher than in unilateral pneumothorax

Table 2. Demographic data and side of pneumothorax

\begin{tabular}{|c|c|c|c|}
\hline & Group T $(n=57)$ & Group I (n=12) & $\mathbf{p}$ \\
\hline Age (year) & $30.16 \pm 18.93$ & $40.17 \pm 19.32$ & 0.102 \\
\hline \multirow[t]{2}{*}{ Gender } & $37 \quad 64.91 \%$ & $10 \quad 83.33 \%$ & 0.213 \\
\hline & $20 \quad 35.09 \%$ & $16.67 \%$ & \\
\hline Height (cm) & $154.19 \pm 30.25$ & $160.67 \pm 22.6$ & 0.487 \\
\hline Weight (kg) & $64.79 \pm 25.3$ & $71.58 \pm 16.74$ & 0.378 \\
\hline APACHE II score & $21.23 \pm 5.32$ & $23.16 \pm 5.84$ & 0.108 \\
\hline \multirow[t]{3}{*}{ Side of pneumothorax (R/L/RL) } & $\mathrm{R}=22$ & $\mathrm{R}=9$ & 0.046 \\
\hline & $L=22$ & $\mathrm{~L}=3$ & \\
\hline & $\mathrm{RL}=13$ & $\mathrm{RL}=0$ & \\
\hline \multirow[t]{3}{*}{ Radiological diagnostic method (chest X-ray, CToT) } & Chest X-ray $=2$ & Chest X-ray $=6$ & 0.039 \\
\hline & $\mathrm{CTOT}=37$ & $\mathrm{CToT}=2$ & \\
\hline & Both $=18$ & Both $=4$ & \\
\hline Presence of thoracentesis for diagnosis & $13(22.81 \%)$ & $3(25 \%)$ & 0.091 \\
\hline
\end{tabular}

APACHE: Acute physiology and chronic health evaluation, R: Right, L: Left, RL: Bilaterally, CToT: Computed tomography of thorax, Group T: Traumatic Pneumothorax group, Group I: latrogenic Pneumothorax group

\begin{tabular}{|c|c|c|}
\hline \multicolumn{3}{|c|}{ Pneumothorax } \\
\hline \multirow{2}{*}{$\begin{array}{l}\text { Spontaneous } \\
(n=0)\end{array}$} & \multicolumn{2}{|l|}{ Primary $(n=0)$} \\
\hline & \multicolumn{2}{|l|}{$\begin{array}{l}\text { Secondary } \\
(n=0)\end{array}$} \\
\hline \multirow{7}{*}{$\begin{array}{l}\text { Acquired } \\
(n=69) \\
(100 \%)\end{array}$} & \multirow{5}{*}{$\begin{array}{l}\text { Group T } \\
(n=57) \\
(82.61 \%)\end{array}$} & $\begin{array}{l}\text { Traffic accident }(n=19) \text {, } \\
\text { Stab wounds }(n=10)\end{array}$ \\
\hline & & Firearm injury $(n=3)$, \\
\hline & & Polytrauma $(n=23)$ \\
\hline & & Barotrauma $(n=1)$, \\
\hline & & CPR-Chest compression $(n=1)$ \\
\hline & $\begin{array}{l}\text { Group I } \\
(n=12)\end{array}$ & $\begin{array}{l}\text { Central venous cannulation }(n=8) \text {, } \\
\text { Thoracentesis }(n=3) \text {, }\end{array}$ \\
\hline & $(17.39 \%)$ & $\begin{array}{l}\text { ARDS-Mechanical ventilation } \\
\text { support }(n=1)\end{array}$ \\
\hline
\end{tabular}

CPR: Cardiopulmonary resuscitation, ARDS: Acute Respiratory Distress syndrome, Group T: Traumatic Pneumothorax group, Group I: Iatrogenic Pneumothorax group

\begin{tabular}{|c|c|c|c|}
\hline & $\underset{(n=57)}{\text { Group } T}$ & $\begin{array}{l}\text { Group I } \\
(n=12)\end{array}$ & $\mathbf{p}$ \\
\hline $\begin{array}{l}\text { Chest tube insertion time } \\
\text { (hour) }\end{array}$ & $1.11 \pm 0.38$ & $5.33 \pm 5.3$ & 0.0001 \\
\hline $\begin{array}{l}\text { Duration of chest tube } \\
\text { drainage (day) }\end{array}$ & $8.04 \pm 4.01$ & $7.17 \pm 4.41$ & 0.511 \\
\hline $\begin{array}{l}\text { Duration of mechanical } \\
\text { ventilation (day) }\end{array}$ & $12.53 \pm 18.53$ & $24.25 \pm 40.15$ & 0.03 \\
\hline ICU stay (day) & $15.46 \pm 19.79$ & $32.5 s \pm 39.33$ & 0.02 \\
\hline Mortality & $15(26.32 \%)$ & $6(50 \%)$ & 0.105 \\
\hline
\end{tabular}


(9). In our cases, incidence of bilateral pneumothorax was higher. This resulted from the fact that the etiology of most of our cases was injuries associated with polytrauma. The treatment modality in traumatic pneumothoraxes depends on the clinical status of the patient, the severity of the pneumothorax, time of occurrence of the trauma, whether the patient will require support ventilator, or whether the patient will receive anesthesia (10). It is clear that a pneumothorax that might be overlooked when a patient who has had a trauma has additional conditions will dramatize the situation even more (11). Therefore, it not a preferable method to stay conservative and to not follow up the patient in the presence of a pneumothorax in trauma patients (12). Chest tube duration and ICU length of stay in the case of the patients inserted with a chest tube due to traumatic pneumothorax were longer compared to iatrogenic pneumothorax.

Chest X-ray is the first choice as an imaging technique for the diagnosis of pneumothorax (13). Expiratory films and lateral decubitus films are not recommended as a routine. However, the literature recommends these films in case of a highly suspected pneumothorax in patients with normal anterior-posterior chest X-rays (14). Nevertheless, CToT provides a definitive diagnosis in undiagnosed cases (15). In the patients scanned retrospectively, combination of chest $\mathrm{X}$-ray and CToT was more common as the first diagnostic imaging method. This is because most of the patients had polytrauma and scanning of all cavities with computed tomography was a routine method of diagnosis.

In our study, $17.39 \%$ of all ICU pneumothorax cases were iatrogenic pneumothorax. Sassoon et al. (16) determined the causes of iatrogenic pneumothorax as transthoracic needle biopsy, CVC and thoracentesis in the order of incidence. The most common cause of iatrogenic pneumothorax in ICUs is CVC (17). When deciding on the side to be catheterized, it should be carefully evaluated by examining the preoperative chest X-ray whether there are any apical bullae, rib and clavicula anomalies and Chronic Obstructive Pulmonary disease. Catheterization of the side of the hemithorax on which it is planned to operate in patients that will undergo thoracic surgery and catheterization of the traumatic hemithorax in patients that have had a thoracic trauma aim to protect against the risk of iatrogenic pneumothorax (18). Pneumothorax associated with CVC is more common in the right hemithorax (19). In our study, it was detected that the right hemithorax involvement was higher in iatrogenic pneumothorax cases. This is mainly because the central veins associated with the right hemithorax are preferred for CVC in the absence of any contraindication, which is easier, more ergonomic and more customary (20). CVC may not be easy to perform due to several reasons like anatomic differences, obesity, hypovolemia and vascular pathologies or lack of experience (21). Recurring punctures increases the likelihood of complications (22). It is pointed out that, in relation to occurrence of pneumothorax after invasive interventions, the experience of the operating doctor is important, risk of complication decreases with increasing experience, thus residents need to perform invasive operations under the supervision of specialists throughout their training (23). Today, vascular puncture has become easier during CVC with use of ultrasound devices in ICUs, with a decrease in complications like pneumothorax (24). Even though a chest X-ray taken at the end of expiration can be a guide when making a diagnosis, Molgaard et al. (25) reported that routine chest $\mathrm{X}$-rays are not valuable for early diagnosis in their study on 473 CVC cases analyzed in relation to pneumothorax. All patients' posterior-anterior chest X-rays are obtained after they undergo a CVC in our ICU. In case of iatrogenic pneumothorax, partial pneumothorax may progress into total pneumothorax and even tension pneumothorax, leading to sudden death when PPMV is applied in the absence of onset symptoms. Despars et al. (26) reported that two out of 98 patients who developed iatrogenic pneumothorax died of this reason and one patient who could not be diagnosed with pneumothorax developed tension pneumothorax. In our iatrogenic pneumothorax cases, the total mortality rate was found to be $50 \%$. This was attributed to the comorbidities of the patients. We found out that, out of six iatrogenic pneumothorax cases that resulted in exitus, one had a post-cardiac arrest, one had lung cancer, one had esophageal cancer, and one was monitored in our ICU due to traffic accident-polytrauma. Since the patients with said diagnoses had high APACHEII scores, the expectancy of mortality was also extremely high.

In our study, it was found out that ICU lengths of stay of patients were higher in the Group I than the Group T. Another statistically significant difference between the two groups was the time of insertion of thoracic tube. The thoracic tube was inserted earlier in the traumatic cases compared to the iatrogenic cases. This was because the traumatic cases had already had pneumothorax at the time they were first admitted to the ICU and the iatrogenic cases developed pneumothorax after they spent certain amount of time in the ICU (on the day of the interventional 
procedure). Another significant difference was the localization of the pneumothorax. Whereas the location of the thoracic tube was the right side in 22 , the left side in 22 and the bilateral sides in 13 cases in the traumatic group, 9 cases had pneumothorax in the right side, 3 had pneumothorax in the left side and no cases had bilateral pneumothorax in the iatrogenic group. The main reason for this difference is that traumatic pneumothorax can involve either of or both hemithoraces depending on the trauma whereas iatrogenic cases are limited to the side which is operated on.

Limitations of our study included its retrospective study design, limited number of cases, study population limited to critical illness patient, study setting in a single center's ICU, and possibility of diagnostic records deficiency in hospital data system.

\section{Conclusion}

In conclusion, pneumothorax is one of the most frequent emergencies encountered in ICUs (27). Therefore, doctors of ICU should know well what to pay attention to in pneumothorax patient management (diagnosis, followup, treatment) (28). Performance of invasive operations by experienced personnel will result in less frequent occurrence of iatrogenic pneumothorax cases.

\section{Ethics}

Ethics Committee Approval: This study retrospectively examined the records of total of 2.839 patients followed up and treated in the Anesthesiology and Reanimation Clinic ICU of our hospital between the dates 01.01.2013 and 01.01.2015 having obtained local ethics committee approval.

Informed Consent: Written consent was obtained.

Peer-review: Externally peer-reviewed.

\section{Authorship Contributions}

Concept: A.Ö., K.E., M.S.S., Design: S.D., M.S.S., S.D., Data Collection or Processing: F.G.Ö., K.E., A.S., Analysis or Interpretation: A.Ö., S.D., A.S., Literature Search: A.Ö., M.W., M.S.S., Writing: A.Ö., A.S.

Conflict of Interest: No conflict of interest was declared by the authors.

Financial Disclosure: The authors declared that this study received no financial support.

\section{References}

1. Yarmus L, DO, Feller-Kopman D. Pneumothorax in the critically ill patient. Chest 2012;141:1098-1105.

2. Strange C. Pleural complications in the intensive care unit. Clin Chest Med 1999;20:317-327.

3. Bozkurt K. Pneumothorax. Solunum 2002;4:206-209.

4. Henry M, Arnold T, Harvey J. BTS guidelines for management of spontaneous pneumothorax. Thorax 2003;58:39-52.

5. Lichtestein DA, Menu Y. A bedside ultrasound sign ruling out pneumothorax in the critically ill. Lung sliding. Chest 1995;108:1345-1348.

6. McGee DC, Gould MK. Preventing complications of central venous catheterization. N Engl J Med 2003;348:1123-1133.

7. Chen KU, Jerng JS, Liao WY, Ding LW, Kuo LC, Wang JY, et al. Pneumothorax in the ICU. Chest 2002;122:678-683.

8. Er M, Işık AF, Kurnaz M, Çobanoğlu U, Sağay S, Yalçınkaya İ. Göğüs travmalı 424 olgunun sonuçları. TJTES 2003;9:267-274.

9. Tekinbaş C, Eroğlu A, Kürkçüoğlu İC, Türkyılmaz A, Yekeler E, Karaoğlanoğlu N. Toraks travmaları: 592 olgunun analizi. TJTES 2003;9:275-280

10. İmamoğlu OU, Öncel M, Erginel T, Tunçay E, Dalkılıç G, Acar H, et al. Toraks travmalarında yaklaşım: 110 olgunun değerlendirilmesi. Türk Gögüs Kalp Damar Cer Derg 1999;7:450-453.

11. Özçelik C, Balcı AE, Eren S, Ülkü R, Dablan M, Eren N. Toraks travmaları (10 yıllık deneyim). TJTES 2000;6:44-49.

12. Weissberg D, Refaely Y. Pneumothorax: experience with 1199 patients. Chest 2000;117:1279-1285.

13. Hefny AF, Kunhivalappil FT, Paul M, Almansoori TM, Zoubeidi T, Abu-Zidan FM. Anatomical locations of air for rapid diagnosis of pneumothorax in blunt trauma patients. World J Emerg Surg 2019;14:44.

14. Ley-Zaporozhan J, Shoushtari H, Menezes R, Zelovitzky L, Odedra D, Jimenez-Juan L, et al. Enhanced pneumothorax visualization in ICU patients using portable chest radiography. PLoS One 2018;13:e0209770.

15. Huang Y, Huang H, Li Q, Browning RF, Parrish S, Turner JF, et al. Approach of the treatment for pneumothorax. J Thorac Dis 2014;6:416-420.

16. Sassoon CS. The etiology and treatment of spontaneous pneumothorax. Curr Opin Pulm Med 1995;1:331-338.

17. Laronga C, Meric F, Troung MT, Mayfield C, Mansfield P. A treatment algorithm for pneumothoraces complicating central venous catheter insertion. Am J Surg 2000;180:523-526; discussion 526-527.

18. Raman D, Sharma M, Moghekar A, Wang X, Hatipoğlu U. Utilization of Thoracic Ultrasound for Confirmation of Central Venous Catheter Placement and Exclusion of Pneumothorax: A Novel Technique in Real-Time Application. J Intensive Care Med 2019;34:594-598.

19. Terzi E, Zaragoulidis K, Kougioumtzi I, Mpoukovinas I, Karavasilis V, Lampaki S, et al. Acute respiratory distress syndrome and pneumothorax. J. Thorac Dis 2014;6:435-442.

20. Papagiannis A, Lazaridis G, Zaragoulidis K, Papaiwannou A, Karavergou A, Lampaki S, et al. Pneumothorax: an up to date “introduction". Ann Transl Med 2015;3:53. 
21. Iqbal SI, Molgaard C, Williamson C, Flacke S. Purposeful creation of a pneumothorax and chest tube placement to facilitate CTguided coil localization of lung nodules before video-assisted thoracoscopic surgical wedge resection. J Vasc Interv Radiol 2014;25:1133-1138.

22. Ioannidis G, Lazaridis G, Baka S, Mpoukovinas I, Karavasilis V, Lampaki S, et al. Barotrauma and pneumothorax. J Thorac Dis 2015;7:38-43.

23. Frykholm P, Pikwer A, Hammarskjöld F, Larsson AT, Lindgren $\mathrm{S}$, Lindwall $\mathrm{R}$, et al. Clinical guidelines on central venous catheterisation. Swedish Society of Anaesthesiology and Intensive Care Medicine. Acta Anaesthesiol Scand 2014;58:508-524.

24. Ashton-Cleary DT. Is thoracic ultrasound a viable alternative to conventional imaging in the critical care setting? BJA 2013;111:152160.
25. Molgaard O, Nielsen MS, Handberg BB, Jensen JM, Kjaergaard J, Juul N. Routine X-ray control of upper central venous lines: Is it necessary. Acta Anaesthesiol Scand 2004;48:685-689.

26. Despars JA, Sassoon CS, Light RW. Significance of iatrogenic pneumothoraces. Chest 1994;105:1147-1150.

27. Ayed AK, Chandrasekaran C, Sukumar M. Aspiration versus tube drainage in primary spontaneous pneumothorax: a randomised study. Eur Respir J 2006;27:477-482.

28. Danish M, Agarwal A, Goyal P, Gupta D, Lal H, Prasad R, et al. Diagnostic Performance of 6-Point Lung Ultrasound in ICU Patients: A Comparison with Chest X-Ray and CT Thorax. Turk J Anaesthesiol Reanim 2019;47:307-319. 